Aneta DAW IDOW ICZ (D)

Maria Curie-Skłodowska University, Faculty of Political Science, Lublin, Poland

\title{
The Nation in the Political Thought of the National Party (1928-1939) ${ }^{1}$
}

Naród w myśli politycznej Stronnictwa Narodowego (1928-1939)

\section{- Abstrakt •}

Kategoria narodu, będąc jednym z obiektów badań nauk społecznych i humanistycznych, stała się ważnym pojęciem w teorii kształtującej się socjologii oraz w psychologii społecznej. Inspirowała do przemyśleń politycznych, prawnych, historycznych, filozoficznych, psychologicznych, etnograficznych. Wyróżnikiem myśli politycznej SN było stałe podkreślanie nadrzędności narodu wobec jednostki. W poglądach SN naród występował w funkcji podmiotu, stosunek zaś jednostki do niego stanowił podstawową wartość moralną. Uważano, że jednostkę i naród łączyły więzy uczuciowe. Refleksja nad narodem, jego istotą i funkcją była kluczowym motywem w myśli politycznej SN. Naród polski traktowano jako podmiot. Głoszono zasadę hierarchicznej organizacji narodu. W twórczości ideologów SN idea narodu zawierała silny potencjał emocjonalny, ściśle związany z aspektem moralnym. Niezmiennie

\section{- Abstract •}

A reflection on the nation, its essence and function formed the key motivation in the National Party's political thought. The Polish nation was treated subjectively, and the principle of a hierarchical nation organisation was disseminated. In the works by the National Party ideologists, the idea of the nation presented a strong emotional potential, closely related to a moral aspect. It was invariably proclaimed that the nation was a spiritual body. The National Party theorists were convinced that the national idea added real meaning to all forms of a person's functioning. The Party members viewed the nation as such an important and priority issue that any indifferent personal approach towards the nation was considered unacceptable. It can be noted that, contrary to previous statements, typical of "the early nationalism" (at the turn of the $20^{\text {th }}$ century), the nation was no longer treated as the absolute, but rather it was viewed through the prism of its

1 This article was drawn up within the framework of the research project entitled "The National Party's Political Thought in 1928-1939", financed from the resources granted by the National Science Centre under decision No. DEC-2013/09/B/HS5/00016. 
głoszono myśl, iż naród stanowi istotę duchową. W przekonaniu teoretyków SN idea narodowa nadawała treść wszelkim formom funkcjonowania człowieka. Naród był w poglądach SN zjawiskiem tak ważnym i priorytetowym, że niedopuszczalna była obojętność jednostki wobec niego. Pojmowano go w relacji do Boga i świata wartości transcedentalnych. Określano go najczęściej jako rodzaj rodziny, niepowtarzalny byt o charakterze metafizycznym, dobitnie akcentując duchową i moralną postać narodu.

Słowa kluczowe: myśl polityczna; Stronnictwo Narodowe; nacjonalizm; system polityczny; naród relation to God and the world of transcendental values. It was usually considered a kind of family, and a unique metaphysical being, with a strong emphasis placed on the spiritual and moral form of the nation.

Keywords: political thought; National Party; nationalism; political system; nation

\section{Preliminary Remarks}

Views of the National Party (1928-1939) merit special attention, given both the Party's prominent role in the political life of interwar Poland, and the interesting combination of various elements derived from diverse ideological trends within the Party's programme. The ideological legacy of the National Party reflected, to a large extent, the key constituents of the National Democracy's political thought, such as nationalism, representation of all social classes, national integrity, and the concept of the nation-state. The National Party underwent major evolution, and was subject to internal divisions, which makes the image of its political thought much more complex.

The National Party's ideological contribution to nationalist political thought, and - broadly speaking - to Polish and European political thought, was significant. The National Party's political thought covered a wide range of ideological, political, systemic, historiosophical, philosophical, pedagogical, social, and economic issues. Its creators developed a vision of multiple categories referring, inter alia, to the nation, the state, political power, the economy, society, national education, the attitude to Catholicism, the status of national minorities and foreign policy, as well as external and internal security.

The National Party's political thought was determined by diverse ideological, political, social and economic factors. The most significant ones included: (1) the authoritarian state model implemented by the pro-Piłsudski formation; (2) the development of anti-democratic and anti-parliamentary tendencies in Europe; (3) the development of totalitarian movements within many European countries; 
(4) the growing political and military potential of Germany; and (5) the huge economic crisis and its numerous social implications.

The principal objective of this article is to present selected elements of the National Party's views on the state's political system in the context of political science. Other objectives include outlining the ideological, conceptual and programme-related image of the National Party, along with the factors determining its ideas, concepts, and views, regarding the state's political system.

Analysis of the previous studies on this subject-matter has revealed that the scientific reflection on Polish nationalism is still incomplete, and calls for extensive verification. The subject matter dealt with in this article has filled in a major research gap.

Induction was the underlying research method employed by the author. Among the research techniques used in the study, the analysis of various proofs and traces of political thought became the most prevalent. Other research methods which proved useful in implementing the research objectives included the systematisation of political concepts and a description based on a status quo analysis.

The nation, as the subject-matter of scientific and humanistic research, has become a significant notion among sociological and social psychology theories, inspiring political, legal, historical, philosophical, psychological and ethnographic deliberations. Enthusiasm for such considerations was expressed by prominent founders of Polish political thought representing various ideological viewpoints, including Bolesław Limanowski, Bolesław Wysłouch, Jan Ludwik Popławski, Zygmunt Balicki, Roman Dmowski, Kazimierz Kelles-Krauz, Stanisław Brzozowski, Edward Abramowski and Ludwik Gumplowicz. Some of their reflections still enjoy much interest among researchers, and continue to be seen as thought-provoking topics of scientific debate (Bystroń, 1916; Szacki, 2002; Jasińska-Kania, 2010, pp. 76-77).

By analysing the numerous and diverse accounts of the National Party's political thought, the conclusion can be drawn that the Party's ideologists viewed the nation as a difficult notion to define, and as a challenging subject for thorough synthesis. Imprecise formulations of the vision of the nation, difficulties in identifying its universal features, and huge emotional resonance, were reflected in several definitions of that notion.

Perceiving the nation as the highest political value can be considered a distinguishing feature of all nationalistic movements. Such an approach was also manifested by the political thought of the founders of the National Party (1928-1939). The idea of the nation's primacy was approached from a number of different angles. In the National Party's political programme dated 1928, emphasis was placed 
on the nation, in contrast to statehood (Kornaś, 2005, p. 22). Written opinions were expressed that "the Polish nation is the creator of the Polish State, and the only permanent source of its power. Presenting the statehood principle in contrast to the national principle is both erroneous and destructive"1. The nation's being considered a central value, implicating the preferred order of values, and the attention paid to the separate interests of various nations, were the two features which made the views of the National Party ideologists clearly distinguishable from those held by other political entities. The essence of the Polish nation, and its well-being and development, became the matters of primary interest, and the strongest motivation for most political concepts and views.

In the National Party's political thought, the nation was seen as a value with a determining impact on other elements forming the catalogue of values. Among the national ideologists, the term "nation" was eagerly used in relation to any phenomena within a person's interest - (1) the system of preferred values was considered national, and so was (2) the character of political activities. In addition, (3) social, economic and cultural activities were seen as having a national dimension. Such an approach was also reflected in the Party's name proposed by Roman Dmowski. He justified abandoning the traditional name, i.e., the Democratic National Party, by stating that the Party would no longer aim at the increased democratisation of the State ${ }^{2}$.

\section{Christian Nationalism}

Differences between nationalists are hardly unexpected, as various types of nationalism tend to fundamentally differ. However, the extent of such differences seems to be an open question. The forms of nationalism can be classified in a number of ways (Strutyński, 2006, p. 9). A sub-discipline of political science, referred to as the political science of religion, distinguished three major types of nationalism, taking into account the kinds of relationship between nationalism and religion, i.e., (1) secular nationalism, (2) Christian nationalism, and (3) neo-pagan nationalism (Banek, 2001, pp. 18-23). The development of secular (laic) nationalism was influenced by secular values, according to which religion

\footnotetext{
1 Program Stronnictwa Narodowego uchwalony przez Radę Naczelną Stronnictwa dnia 7 października 1928 roku [The National Party's Programme Adopted by the Party's Chief Council on 7 October 1928], Warszawa 1928, p. 4.

2 Przemówienie senatora Joachima Bartoszewicza [A Speech by Senator Joachim Bartoszewicz] (1935), Gazeta Warszawska, 24, 6, January 21.
} 
and churches were merely viewed as real facts, operating in the social, cultural and political domains. In its ideas and assumptions, secular nationalism did not consider the requirements stipulated by religions and religious institutions. In Poland, Zygmunt Balicki was the principal creator and representative of secular nationalism. Nonetheless, unlike in neighbouring countries, including Ukraine and Germany, this form of nationalism did not enjoy long-term interest in our country (Dawidowicz, 2006, pp. 191-232).

Catholicism was an axiological pillar of the National Party. The form of nationalism represented by the Party sought to justify its ideas and concepts through religious values and the Catholic Church's teachings. The term "Christian nationalism" regularly appeared in the National Party's programme statements. As written by journalist Zofia Żółtowska-Dąbrowska, it was the domain within which "a harmony of freedom and obligation which ultimately forms the core of moral Catholic teaching" (Źółtowska-Dąbrowska, 1933, p. 389) could be found. By negating the collection of values and cultural conditions which had evolved throughout the $19^{\text {th }}$ century, and by perceiving them as unfavourable from the point of view of the nationalism represented by the "young" members of the National Party (also referred to as Endecja), its representatives turned to Catholicism. It was viewed not only as an ideology but also as a set of social and moral standards contradicting the so-called $19^{\text {th }}$-century ideology.

Under the influence of Catholic values, previously valid notions and concepts were negated. In particular, the concept of two moral philosophies, i.e., national and Christian, was abandoned, and the nation was no longer treated as an absolute. As indicated by Bogumił Grott, Christian ethics were intended, inter alia, to regulate the relationships between people and nations, and the relationships between various nations. Such values as the nation and motherland acquired a religious dimension, and formed part of the Christian worldview, having lost their original self-sufficiency, which they had represented in the framework of secular nationalism (Grott, 1996, p. 76).

The National Party did not perceive the nation as an absolute in ideological terms. As proven by the title of Jędrzej Giertych's publication, the Party represented the Christian (Catholic) type of nationalism. Its members distanced themselves from any kind of non-Christian nationalism, disapproving of any attempts at nation absolutisation. The perception of the nation as the ultimate value was seen as a feature of pagan nationalism. "Treating the nation - as some representatives of the extreme forms of nationalism tend to do - as the absolute value, to which justice, law and morality should yield, and for which nothing can be considered sinful or criminal, as long as it serves its purpose, is clearly a pagan view", Gier- 
tych wrote. The journalist also emphasised that the nation's well-being could not constitute the ultimate goal, as this function was solely attributable to God. The nation's well-being, though very important, should yield to God's laws. Giertych seemed to have no doubt that the nation was merely an earthly value. "(...) The nation's well-being, as the well-being of any family, must be subordinated to moral law" (Giertych, 1977, p. 14).

\section{Criticism of National Egoism}

The National Party clearly went away from the concept of national egoism formulated at the beginning of the $20^{\text {th }}$ century by Zygmunt Balicki (Dawidowicz, 2004, pp. 177-191). The dual ethical system and the predominance of national ethics were strongly criticised. In his work entitled Christian Nationalism, Jędrzej Giertych unambiguously stated "there was once a danger of the Party's (i.e., the National Democracy - A.D.) following the same direction as the French or Italian nationalist movements, i.e., supporting the pagan perception of the nation as the absolute value and setting the nation free from its ethical ties. This danger was best reflected in a book written nearly half a century ago by Zygmunt Balicki, entitled The National Egoism's View on Ethics. Fortunately, it has disappeared without a trace" (Giertych, 1948, p. 46). Similar opinions were expressed by Adam Doboszyński, a representative of the "young" generation, who treated the slogan of national egoism as passé and no longer valid. Doboszyński advocated that "our generation has finally realised that the national sentiment, which should act as a building block rather than an explosive, needs to be supplemented by the universalist sentiment. One cannot be a complete man if he does not love his nation. This love, however, must not turn a blind eye on the rights vested in other people to cherish other nations" (Doboszyński, 1941, pp. 6-7). Also, Roman Dmowski himself admitted that the national egoism slogan had constituted a major vehicle for boosting national energy before 1918, but in the 1930s, along with the progressing turn to Catholicism in the national camp, it was no longer applicable ${ }^{3}$.

3 The Jagiellonian Library, Fragments of Ignacy Chrzanowski's Work about Roman Dmowski, File No. 9996 III, Akc. 168/55, p. 30, Typescript. 


\section{Sources of Views}

The National Party's political thought evolved on the basis of a wide array of ideological sources. While formulating views on the nation, inspiration was drawn from diverse ideological trends. Party members supported the idea expressed by Ernest Renan, a French theorist, that the nation was a spiritual being. For this reason, it could hardly be described by referring to materialistic factors. Romantic ideology served as another source, with its traces found in numerous deliberations on the origins of nations. In line with the romanticists' views, the nation was seen as playing a major role in the Creator's intentions. While pondering on the origins of nations, the National Party journalists had no doubt that they were created by God. "God thinks through nations while thinking about mankind" (Z.W., 1938, p. 589), wrote one of the Myśl Narodowa journalists. At the same time, the Polish romantic concepts and visions of the Polish nation were met with criticism. The idea of Poland's unique mission was not approved by the "young" members of Endecja. They expressed criticism of both national Messianism and the concept that "Poland was the Christ of nations". Wojciech Wasiutyński, speaking on behalf of "the young", wrote " $[t]$ he aimless cult of suffering and sacrifice is strange to the young generation. We tend to be ashamed of suffering, and yielding to violence hurts us as if it were a personal insult" (Wasiutyński, 1931, pp. 111).

Zygmunt Wasilewski, one of the National Party journalists, supplemented the above statement by reflecting on the relationship between the soul and national culture. As a literary critic and historian, culture expert and folklore researcher with exceptional editorial, journalistic and ideological skills, Wasilewski believed that the nation could not exist without culture. “(...) culture is the nation's soul and body” (Wasilewski, 1937, pp. 567; Dawidowicz, 2012, pp. 71-90) he claimed. According to the National Party's thinkers, culture was an extremely important nation-building factor. Wasilewski, who clearly emphasised the role of culture in his writings, claimed that it was a factor shaping national ties and identity, which was why it appeared essential to preserve the national shape of the Polish culture. Wasilewski frequently expressed this view in his articles published in numerous national journals. According to him, "a good culture is aimed at educating an ambitious man, and a master in his own nation. If we let ourselves be intimidated, Poland's role will be limited - which is a dreadful perspective - to that of an idle observer of nations, convinced of its own powerlessness" (Wasilewski, 1937, p. 568). In numerous accounts, opinions were expressed that the Polish nation, influenced by foreign culture, unclear ideas and values, would dwindle, degenerate and die away. In order to prevent this situation, Roman Rybarski, who was anoth- 
er prominent national thinker, recommended nourishing the Polish culture, native values and traditions, rather than following destructive foreign ideas. "Beware of both sarmatism and foreignness (...) Abstain from neglecting your own values, (...) a superficial assimilation of foreign ideas does not raise creative powers in the Polish nation" (Rybarski, 1933, p. 766), he warned when addressing his readers. The National Party thinkers were deeply convinced that the influence of foreign trends would weaken the nation, contribute to its denaturisation, and pave the way to moral degeneration.

\section{Tradition}

While staying attentive to the development of the Polish nation, much consideration was given to tradition, which, according to the National Party, acted as a consolidating factor. In the catalogue of permanent and authentic values, tradition invariably held a prominent place. It was seen as preserving permanent and authentic values, so constituting a factor contributing to the consolidation of Polish people's national identity. According to the National Party, national tradition formed a major source of the nation's power, helped to build its future, and fostered its national identity. As advocated by Karol Stefan Frycz, a representative of the young generation in the national camp, “(....) the nation cannot go with the flow, but it must keep in with (...) tradition, (...) it must live its own way, within its essence" (Frycz, 1934, p. 813). However, a selective approach to tradition was recommended, with the need to eliminate any adverse and foreign cultural behaviour patterns. "Even tradition is perceived by nationalists as a relative value. We hardly opt for all traditions. Actually, the ones that we need to contradict are numerous" (Stojanowski, 1936, p. 258).

It was believed that, contrary to European nations, the Polish nation displayed a multitude of bio-psychological and civilisation features ${ }^{4}$. Among the National Party members, voices appeared that the nation was a historical and political community. For Karol Stefan Frycz, a young journalist at Myśl Narodowa, the Polish nation exemplified a historical nation. It was "the nation that has its history - this statement being far from cliché, because not all nations have their history, and they are not uniform" (Frycz, 1936, p. 274). As advocated by Joachim Bartoszewicz, President of the National Party, "the nation is a historical and political

${ }^{4}$ The New Files Archive, Warsaw, A Collection of the National Camp's Documents. Ideological and Educational Materials, File No. 25. Our Look Backwards, p. 5. 
formation. This is a relationship of people who, in a longer period of an uninterrupted political existence, have developed a uniform way of looking at the most important issues related to their motherland's existence and development". "(...) For us, the nation is not only an ethnographic notion, but it obviously comprises such factors as origin, religion and language. (...) We perceive the nation as a political organisation"

\section{The Catholic Character of the Polish Nation}

While describing the nation, national journalists strongly accentuated the Catholic character of the Polish nation. As it was markedly emphasised, "(...) the Polish nation is a Catholic nation" (Giertych, 1948, p. 51). In any attempts at placing the Polish nation among European nations, its Catholic character was distinctly stressed. Jędrzej Giertych did not hesitate to say "apart from Spain, there is no other nation in the world that would be as strongly Catholic as we are". Giertych was pleased to identify the common features of Carlism and the National Party's ideology, referring to similar worldviews. "When talking to a representative of Carlism, I get the impression that, while our opinions could differ in various matters (...), our overall view of the world is the same. In neither of us are the religious, or Catholic, feelings reflected in typical Christian-democratic softness, tolerance and leniency, but they have distinctive accents, which could be associated with the Crusaders' steel arms rather than with the opportunistic slogans so frequently shared by pseudo-Catholic politicians. Both of us have the same sense of dislike for the modern $19^{\text {th }}$-century ideologies" (Giertych, 1937, pp. 148-149). The leaders of the National Party, representing Christian nationalism, saw the emergence and development of national structures as conditional on the consolidation of the Christian civilisation in Europe. Jędrzej Giertych advocated " $[t]$ he nation, in the strict and full sense of this word, is a product of Christian civilisation. It started to emerge not earlier than in the Middle Ages, but, despite being a young formation, it has already become a fact".

The National Party ideologists, having abandoned the secular point of view, praised the religious attitudes in European civilisation. A return to the status quo within which religion would shape the standards governing all aspects of public and social life was strongly advocated. While opposing "the culture of modernity", support was expressed for returning to the worldview based on Catholic values.

\footnotetext{
5 Przemówienie senatora..., p. 6.
} 
As stipulated in the Declaration of the General All-Polish Meeting of the National Party adopted on 30 June 1929, "[t]he life and State system in Poland must be based on an association with the Catholic Church, into which our civilisation has immersed"6.

The traditionalist, if not fundamentalist, character of the National Party's views was reflected in the political writings of the leading thinkers forming part of the "youth" circle. In the National Party's programme brochure, entitled $O w y$ jście z kryzysu, Jędrzej Giertych expressed the following opinion, “(...) everything which was once traditional in the Polish nation (...), attached to the national past, (...) or to religion, or which reflected aversion to cosmopolitan elements, instinctive attachment to social order, loyalty to traditional moral values, and mistrust of political, social, ideological and moral novelties - all this has, for many years, formed an almost even whole with Endecja" (Giertych, 1938, p. 32). He then added "We need to revive the religious (...) and normal, old-fashioned and patriarchal family life (...), to revive fairness both in the monetary sense, (...) and in treating one's own duties and work (...), in order to make hypocrisy vanish (...)".

The creators of the National Party's political thought, attempting at putting Catholicism in the predominant position, were extremely pleased to observe the growing religiousness in Polish society. It was viewed as a positive phenomenon, heralding the process of the rebirth of the nation's moral standing. According to Jan Dobraczyński, the return wave of piousness was unquestionable. "We should stress that this is not only about formal religiosity, reflected in attending certain services, etc., but also about the actual religiosity, inducing an increased number of people to truly experience their religion. Catholicism should not only be followed but also experienced, as only then it can - as it should - become the central point of human life" (Dobraczyński, 1938, p. 81), he wrote.

\section{Psychological and Metaphysical Motives}

When compared to the former views on the nation, formulated by the National Party at the turn of the $20^{\text {th }}$ century, and by leaders and politicians of the Popular National Union in the Reborn Poland's period, the National Party ideologists, while referring to "the nation", frequently cited psychological and metaphysical

${ }^{6}$ Kongres Stronnictwa Narodowego. Deklaracja Walnego Zjazdu Ogólnopolskiego Stronnictwa Narodowego uchwalona w dniu 30 czerwca 1929 roku w Poznaniu [The National Party Congress. A Declaration by the General All-Polish Meeting of the National Party, adopted on 30 June 1929 in Poznań], Myśl Narodowa, 7.07.1929, p. 13. 
motives (Floryńska, 2010, p. 437). While dealing with the issues related to the nation, the Party's ideologists employed anthropomorphism, which involved assigning individual psychological features to the national community. It was believed that the nation and related states of consciousness were strongly rooted in the human psyche. The nation was presented as if it had its own psychological features. National ideologists very frequently wrote about "the nation's psyche" or "the national character". People belonging to a certain national community were said to have some common psychological features which had evolved in a long-lasting historical process, under the influence of culture, traditions and historical events. For some national thinkers, the national character constituted a rather peculiar phenomenon, covering a wide range of values, attitudes and patterns. Attention was paid to psychological differences occurring among various nations. The common national psyche was proven to act as a factor consolidating the nation. According to national journalists, this phenomenon was much more complex and profound than, for instance, language, which was not seen as essential for the national community's existence (Rembieliński, 1930, p. 83).

In the National Party's political thought, the nation was treated as a mental union. Henryk Eysymontt, one of the Party's thinkers publishing articles in Myśl Narodowa, drew attention to the significance of certain patterns represented by "the nation's idea" in the development process of human psyche. According to Eysymont, nationality was the product of the shaping of an individual's personality by the national community, providing grounds for his/her existence. He used the term "national habitus" when referring to the tendencies and dispositions implanted in individuals. Eysymont believed that the nation, through this "habitus", gave rise to a certain mental type of person (Eysymont, 1936, p. 36; Grott, 1984, p. 53).

In the National Party's views, the nation was described as a body with its own psyche. Biological definitions were used much less frequently, and the notion of "race", within its anthropological (material) meaning, tended to be abandoned. However, some National Party activists pointed to the nation's biological characteristics. Examples included deliberations made by Ludwik Jaxa-Bykowski, National Party activist, anthropologist and pedagogue, who stressed the role of the biological strengthening of the Polish nation? ${ }^{7}$ It can, nonetheless, be observed

7 The Archive of the Polish Academy of Sciences, Branch in Poznań, Spuścizny uczonych polskich i ludzi kultury, Spuścizna Ludwika Jaxy-Bykowskiego [The Legacy of Polish Scientists and People of Culture; the Legacy of Ludwik Jaxa-Bykowski], File No. P-III-37, Typescript, Collected Works by L. Jaxa-Bykowski: Nasza mtodzież przed wojna i dziś [Our Youth before the War and Now]; Wychowawcze znaczenie morza [The Educational Significance of the Sea]; Typy woli-temperamenty [Types of Will - Tempers]. 
that the approaches focusing on biological features, or racial issues, in the material sense, appeared more thoroughly and frequently in the views of extremely nationalistic groupings, such as the Falanga National Radical Camp, the National Socialists, and the Zadruga organisation, led by Jan Stachniuk. In contrast to the National Party leaders, the Zadruga organisation "perceived the nation as the ultimate goal", treating it as the social grounding for a collective economic system (Wasiutyński, 1935; Piasecki, 1938).

\section{The Nation as a Community of Generations}

The National Party ideologists tended to perceive the nation as a community of generations. In the Party's programme dated 1928, the nation was also described as "a historical whole" comprising the previous, present and future generations ${ }^{8}$. The nation was seen as a permanent being whose foundations had remained unchanged. In his speech given at the Congress of Commerce and Craft in Ostrołęka in 1936, Józef Psarski said "[i]ndividuals are bound to the nation by a solidarity which is eternal rather than temporary; while generations pass away, the nation, with its efforts and objectives, remains the same (...). A community, in order to function as a nation, must be aware of the separate character of other nations (...). For the community to constitute a nation, it must be bound with unbreakable ties and future, in order to provide the coming generations with an opportunity to pursue both material and spiritual development"9. Similar views were expressed in the Prosto z Mostu [Point-Blank] magazine in 1936 by Jan Mosdorf, Leader of the National Radical Camp. "The previous generations and the entire national future live in every Polish person" (Mosdorf, 1936, p. 3), he wrote. Therefore, in the National Party circles, the nation was understood not only as its currently living members, but also as the previous generations, which constituted - together with the present generation and the generations yet to come - a homogeneous whole, based on the Polish national tradition which had developed throughout

8 The National Library of the Polish Academy of Learning and the Polish Academy of Sciences, Kraków, Józef Zieliński’s Files, mf. 1453, File No. 7825, Program Stronnictwa Narodowego uchwalony przez Radę Naczelną Stronnictwa dnia 7 października 1928 roku [The Programme of the National Party Adopted by the Chief Council on 7 October 1928], Warszawa 1928, p. 120.

9 The National Library in Warsaw. Documents on Social Life. Jobbing Prints Collections. Gtos Ziemi Ostrołęckiej, a Single Publication on the Work of the National Party in the Ostrołęka District, Ostrołęka 1936, Józef Psarski’s Speech at the Commerce and Crafts Congress in Ostrołęka on 21.06.1936. 
the centuries, and on its closely associated role, i.e., the nation's mission in the historical process (Grott, 1984, p. 41). It was stressed in the National Party's political thought that the nation, treated as a continuity of generations, had been formed through a long-lasting historical process. Owing to its tradition, it had its own hierarchy of values, speech, religion, habits, and customs. These components were considered extremely important, because they endowed the nation with a unique character, and it was believed that "the nation is like its generation, and generations are like the individuals who form them" (Koniński, 1934, p. 450).

\section{The Nation as a Living Body}

Inspiration drawn from positivistic organicism can be noted in the National Party's political thought. In line with the views expressed by the theorists representing the early form of nationalism, it was believed that the nation constituted an organic (biological) formation, and, as such, was governed by certain rights, similar to those of a living body. References to the works by Charles Darwin and Herbert Spencer, Social Darwinism authors appeared in the National Party's journalistic writings. In the Social Darwinism doctrine, humanitarian and libertarian ideas were replaced by anti-democratic and anti-individualistic slogans, whereas the nationalistic idea prevailed over the individual value of human beings. As written by Henryk Eysymont in Myśl Narodowa, "the nation is a body, a certain structure which solves the challenge given to people by God, i.e., the challenge of life" (Eysymont, 1936, p. 36). In the National Party's political thought, the nation constituted an organic community whose individual members were bound together by non-material ties corresponding to their common origin, culture, traditions, history and religion. The nation was treated as a biological formation and a harmonious organisation, within which all parts stay together as a harmonious combination.

The perception of the nation as a living body implied that the National Party journalists were convinced of the existence of the nation's soul. They drew their sources of inspiration from intellectual works by European sociologists. By referring to the works of Gustave Le Bon, a French scholar, attempts were made to clarify the term "nation's soul". According to the national journalists, the "nation's soul" shaped (1) the nation's reality and (2) the nation's future, and (3) contributed to the creation of national traditions, historically consolidated beliefs, and even prejudices rooted in the national consciousness. 


\section{The Nation as a Family}

The National Party journalists were disposed to believing that the nation was a family. Such comparisons could be found in numerous opinions expressed on that matter. Descriptions of the nation, treated as an extended family, did not focus on material aspects, but were dominated by psychological, spiritual and cultural issues (Bocheński, 1939, p. 1). The Party's ideologists believed that the similarity of these two structures, i.e., the nation and the family, stemmed from the fact that they both constituted natural communities. A debate on this matter was raised by Jędrzej Giertych. In his publications, he claimed that the spiritual structure of the nation made it similar to a family. "The nation is essentially similar to a family", he wrote. In his opinion, mankind did not consist of separate individuals, but had its hierarchical structure, comprising nations which, in turn, were composed of families. Giertych saw the nation as an extended family, claiming that "[the nation - A.D.] is its higher level". In his view, the nation - similar to a family - constituted a natural community which was not a matter of human choice but was conferred by God. National affiliation was thus viewed as not resulting from any compulsion or willingness of individual members.

Similar views were expressed by Roman Rybarski. Inspired by the works of Georges Sorel, a French thinker, he claimed that the family and marriage had crucial meanings for the nation's functioning (Rybarski, 1933, p. 274). This idea was supported by journalist Karol Stefan Frycz, who claimed "the family stands as the cradle of a healthy society" (Frycz, 1938, p. 74). While stressing the unique and personal character of the family, he explained "there can only be one true family, and, as long as the world exists, no better form than the currently valid one has been discovered. There has to be a father and a mother". The National Party ideologists agreed that both the nation and the family formed the natural living environment for people, offering them support, along with the sense of safety and protection against degenerating factors (Piestrzyński, 1933, p. 241).

\section{Concluding Remarks}

What distinguished the National Party's political thought was continually stressing the superiority of the nation over individuals. The nation was seen as the subject, whereas the attitude of an individual towards the nation formed the principal moral value. It was believed that the unit and the nation had a certain emotional relationship. As claimed by Roman Rybarski, a person's emotions towards the na- 
tion should resemble religious feelings. According to him, faith in the nation and its expansive capacities was part of the national ideal. "One cannot be a nationalist if he does not believe in his nation. No great things can be achieved if the most noble slogans and plans do not launch, inspire, or multiply, the nation's power" (Rybarski, 1938, p. 497), he wrote. For the National Party ideologists, the nation was considered of key value, and the attitude of a person towards the nation was determined by his or her moral standing. It was believed that affection for the nation reflected the human nature of individuals and their moral status.

A reflection on the nation, its essence and function formed the key motivation in the National Party's political thought. The Polish nation was treated subjectively, and the principle of a hierarchical nation organisation was disseminated. In the works by the National Party ideologists, the idea of the nation presented a strong emotional potential, closely related to a moral aspect. It was invariably proclaimed that the nation was a spiritual body. The National Party theorists were convinced that the national idea added real meaning to all forms of a person's functioning. The Party members viewed the nation as such an important and priority issue that any indifferent personal approach towards the nation was considered unacceptable. It can be noted that, contrary to previous statements, typical of "the early nationalism" (at the turn of the $20^{\text {th }}$ century), the nation was no longer treated as the absolute, but rather it was viewed through the prism of its relation to God and the world of transcendental values. It was usually considered a kind of family, and a unique metaphysical being, with a strong emphasis placed on the spiritual and moral form of the nation.

\section{References:}

Banek, K. (2001). Główne problemy politologii religii. Nomos, 34-36, 18-23. Bocheński, A. (1939). Nawet bez szans zwycięstwa. Prosto z Mostu, 16(238), 1. Bystroń, J.S. (1916). Pojęcie narodu w socjologii polskiej. Rok Polski, 15(4), 33-48.

Dawidowicz, A. (2004). System etyczny w myśli politycznej Zygmunta Balickiego. Annales Universitatis Mariae Curie-Skłodowska. Sectio K, Politologia, 11, 177-191.

Dawidowicz, A. (2006). Zygmunt Balicki (1858-1916). Działacz i teoretyk polskiego nacjonalizmu. Kraków: Zakład Wydawniczy „NOMOS”.

Dawidowicz, A. (2012). Zygmunt Wasilewski (1865-1948). Publicysta, dziennikarz, organizator systemu prasowego Narodowej Demokracji. In: E. Maj \& A. Dawidowicz (eds.). Prasa Narodowej Demokracji. Publicyści, Vol. 3: Publicyśsi (pp. 71-90). Lublin: Wydawnictwo Uniwersytetu Marii Curie-Skłodowskiej.

Doboszyński, A. (1941). Wielki naród, Part II: Kirkcaldy.

Dobraczyński, J. (1938). Obowiązek antysemityzmu. Myśl Narodowa, 18(6), 81-83. 
Eysymont, H. (1936). Habitus narodowy. Myśl Narodowa, 16(3), 34-37.

Floryńska, H. (2010). Naród jako byt metafizyczny. Przegląd Filozoficzno-Literacki, 4(29), 435-445.

Frycz, K.S. (1934). Koniec epoki. Myśl Narodowa, 34(55), 813-814.

Frycz, K.S. (1936). Naród historyczny. Myśl Narodowa, 16(18), 274-276.

Frycz, K.S. (1938). Na widowni. Myśl Narodowa, 18(5), 74-75.

Giertych, J. (1937). Hiszpania bohaterska. Warszawa: Ossolineum.

Giertych, J. (1938). O wyjście z kryzysu. Warszawa: Zakł. druk. St. Michalski Cz. Ociepko.

Giertych, J. (1948). Nacjonalizm chrześcijański. Stuttgart: Dom Książki Polskiej.

Giertych, J. (1977). Polski Obóz Narodowy. London.

Grott, B. (1984). Nacjonalizm i religia. Proces zespalania nacjonalizmu z katolicyzmem w jedna całość ideową w myśli Narodowej Demokracji 1926-1939. Kraków: UJ.

Grott, B. (1984). Pojęcie narodu i jego miejsce w hierarchii wartości formacji młodoendeckiej. Przeglad Humanistyczny, 28(9/10), 35-54.

Grott, B. (1996). Nacjonalizm chrześcijański. Narodowo-katolicka formacja ideowa w II Rzeczypospolitej na tle porównawczym. Kraków: Wydawnictwo Ostoja.

Grott, B. (2003). Religia, cywilizacja, rozwój. Wokót idei Jana Stachniuka. Kraków: Zakład Wydawniczy „NOMOS”.

Jasińska-Kania, A. (2010). Narody i nacjonalizm w XX wieku. Przegląd Filozoficzno-Literacki, 4(29), 69-84.

Kongres Stronnictwa Narodowego. Deklaracja Walnego Zjazdu Ogólnopolskiego Stronnictwa Narodowego uchwalona w dniu 30 czerwca 1929 roku w Poznaniu (7.07.1929). Myśl Narodowa, 13.

Koniński, K.L. (1934). Uniwersalizm „dziejowości”. Myśl Narodowa, 14(31), 450-452.

Kornaś, J. (2005). Naród i państwo w myśli politycznej Stronnictwa Narodowego 1928-1939. Zeszyty Naukowe Akademii Ekonomicznej w Krakowie, 692, 21-37.

Mosdorf, J. (1936). Tradycja i tradycjonalizm. Prosto z Mostu, 39(93), 3.

Peretiatkowicz, A. (1928). Jerzy Sorel. Ruch Prawniczy, Ekonomiczny i Socjologiczny, 4.

Piasecki, B. (1938). Walka na dwóch frontach. Warszawa: Wyd. „Przełomu”.

Piestrzyński, R. (1933). Reakcja ustrojowa kierunku narodowego. Myśl Narodowa, 13(18), 241-243.

Program Stronnictwa Narodowego uchwalony przez Radę Naczelną Stronnictwa dnia 7 października 1928 roku (1928). Warszawa.

Przemówienie senatora Joachima Bartoszewicza (21.01.1935). Gazeta Warszawska, 24.

Rembieliński, J. (1930). Poszerzenie ojczyzny. Myśl Narodowa, 10(6), 81-83.

Rybarski, R. (1933). O państwie policyjnem. Myśl Narodowa, 13(20), 273-275.

Rybarski, R. (1933). Własna ideologia gospodarcza. Myśl Narodowa, 13(51), 765-766.

Rybarski, R. (1938). O pojmowaniu idei narodowej. Polityka Narodowa, 8-9, 497.

Stojanowski, K. (1936). Monarchia czy państwo narodowe? Myśl Narodowa, 16(17), 257-260 .

Strutyński, M. (2006). Religia i naród. Inspiracje katolickie w myśli ruchu narodowego w Polsce wspótczesnej (1989-2001). Kraków: „NOMOS”.

Szacki, J. (2002). Historia myśli socjologicznej. Warszawa: Wydawnictwo Naukowe PWN. 
The Archive of the Polish Academy of Sciences, Branch in Poznań, Spuścizny uczonych polskich i ludzi kultury, Spuścizna Ludwika Jaxy-Bykowskiego, File No. P-III-37, Typescript, Collected Works by L. Jaxa-Bykowski: Nasza mtodzież przed wojna i dzis; Wychowawcze znaczenie morza; Typy woli - temperamenty.

The Jagiellonian Library, Fragments of Ignacy Chrzanowski’s Work about Roman Dmowski, File No. 9996 III, Akc. 168/55, p. 30, Typescript.

The National Library in Warsaw. Documents on Social Life. Jobbing Prints Collections. Głos Ziemi Ostrotęckiej, a Single Publication on the Work of the National Party in the Ostrołęka District, Ostrołęka 1936, Józef Psarski's Speech at the Commerce and Crafts Congress in Ostrołęka on 21 June 1936.

The National Library of the Polish Academy of Learning and the Polish Academy of Sciences, Kraków, Józef Zieliński’s Files, mf. 1453, File No. 7825, Program Stronnictwa Narodowego uchwalony przez Radę Naczelna Stronnictwa dnia 7 października 1928 roku, Warszawa 1928, p. 120.

The New Files Archive, Warsaw, A Collection of the National Camp's Documents. Ideological and Educational Materials, File No. 25. Our Look Backwards, p. 5.

Wasilewski, Z. (1937). Na widowni. Myśl Narodowa, 17(36), 566-568.

Wasiutyński, W. (1931). Najmłodsze pokolenie przez pryzmat Myśli nowoczesnego Polaka. Myśl Narodowa, 11(40), 111-113.

Wasiutyński, W. (1935). Naród rządzący. Warszawa: Skład Główny „Dom Książki Polskiej”.

Z.W. (1938). Bóg stworzył narody. Myśl Narodowa, 18(38), 589-590.

Żółtowska-Dąbrowska, Z. (1933). Pacyfizm we Francji a ruch katolicki (dokończenie). Myśl Narodowa, 13(27), 388-390. 